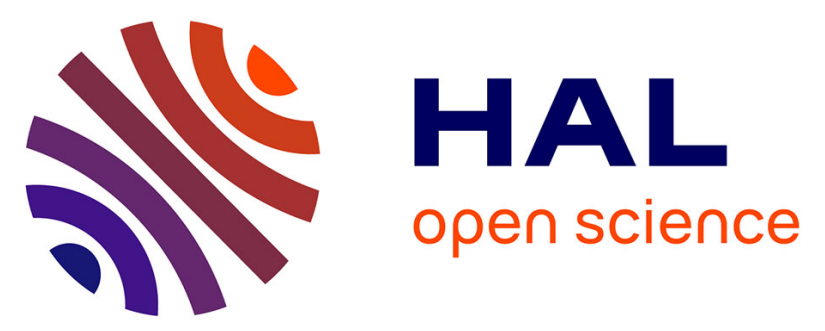

\title{
Safety and Efficacy of Avaren-Fc Lectibody Targeting HCV High-Mannose Glycans in a Human Liver Chimeric Mouse Model
}

Matthew Dent, Krystal Hamorsky, Thibaut Vausselin, Jean Dubuisson, Yoshinari Miyata, Yoshio Morikawa, Nobuyuki Matoba

\section{To cite this version:}

Matthew Dent, Krystal Hamorsky, Thibaut Vausselin, Jean Dubuisson, Yoshinari Miyata, et al.. Safety and Efficacy of Avaren-Fc Lectibody Targeting HCV High-Mannose Glycans in a Human Liver Chimeric Mouse Model. Cellular and Molecular Gastroenterology and Hepatology, 2020, 10.1016/j.jcmgh.2020.08.009 . hal-02992405

\section{HAL Id: hal-02992405 https://hal.science/hal-02992405}

Submitted on 6 Nov 2020

HAL is a multi-disciplinary open access archive for the deposit and dissemination of scientific research documents, whether they are published or not. The documents may come from teaching and research institutions in France or abroad, or from public or private research centers.
L'archive ouverte pluridisciplinaire HAL, est destinée au dépôt et à la diffusion de documents scientifiques de niveau recherche, publiés ou non, émanant des établissements d'enseignement et de recherche français ou étrangers, des laboratoires publics ou privés. 


\section{Safety and Efficacy of Avaren-Fc Lectibody Targeting HCV High- Mannose Glycans in a Human Liver Chimeric Mouse Model}

${ }^{1}$ Department of Pharmacology and Toxicology, ${ }^{2}$ Department of Medicine, ${ }^{3}$ James Graham Brown Cancer Center, ${ }^{4}$ Center for Predictive Medicine, University of Louisville School of Medicine, Louisville, Kentucky; ${ }^{5}$ University of Lille, CNRS, INSERM, CHU Lille, Institut Pasteur de Lille, U1019, UMR 8204, Center for Infection and Immunity of Lille, Lille, France; ${ }^{6}$ PhoenixBio USA Corporation, New York, New York

\section{SUMMARY}

Hepatitis $\mathrm{C}$ virus (HCV) infection remains a major cause of end-stage liver disease. Here, we show the efficacy and safety of a novel biotherapeutic targeting a HCV glycobiomarker in a mouse model, providing a foundation for a new anti-HCV strategy

BACKGROUND \& AIMS: Infection with hepatitis C virus (HCV) remains a major cause of morbidity and mortality worldwide despite the recent advent of highly effective direct-acting antivirals. The envelope glycoproteins of HCV are heavily glycosylated with a high proportion of high-mannose glycans (HMGs), which serve as a shield against neutralizing antibodies and assist in the interaction with cell-entry receptors. However, there is no approved therapeutic targeting this potentially druggable biomarker.

Q7 METHODS: The anti-HCV activity of Avaren-Fc (AvFc) was evaluated through the use of in vitro neutralization assays as Q8 well as an in vivo challenge in the PXB chimeric human liver mouse model. Drug toxicity was assessed by histopathology, serum alanine aminotransferase, and mouse body weights.

RESULTS: AvFc was capable of neutralizing cell culture-derived HCV in a genotype-independent manner, with
$50 \%$ inhibitory concentration values in the low nanomolar range. Systemic administration of $A v F c$ in a histidine-based buffer was well tolerated; after 11 doses every other day at $25 \mathrm{mg} / \mathrm{kg}$ there were no significant changes in body or liver weights or in blood human albumin or serum alanine aminotransferase activity. Gross necropsy and liver pathology confirmed the lack of toxicity. This regimen successfully prevented genotype 1a HCV infection in all animals, although an AvFc mutant lacking HMG binding activity failed.

CONCLUSIONS: These results suggest that targeting envelope HMGs is a promising therapeutic approach against HCV infection, and AvFc may provide a safe and efficacious means to prevent recurrent infection upon liver transplantation in HCVrelated end-stage liver disease patients. (Cell Mol Gastroenterol Hepatol 2020;目-ם; https://doi.org/10.1016/ j.jcmgh.2020.08.009)

Keywords: Hepatitis C Virus; Entry Inhibitor; Plant-Made Pharmaceutical; High-Mannose Glycan; Antiviral Therapy.

工 epatitis C virus (HCV) is an enveloped monopartite Q9 1110 1 positive-sense single-strand RNA virus in the fam- 812114 ily Flaviviridae and the causative agent of hepatitis $\mathrm{C}$ disease. Its genome encodes 3 structural (core, E1, E2) and 7 nonstructural proteins (p7, NS2, NS3, NS4A, NS4B, NS5A, 
and NS5B). ${ }^{1} \mathrm{HCV}$ is highly heterogenous and distributed globally, consisting of 7 genotypes, each subdivided further into multiple subtypes. Genotypes 1 and 2 are the predominant genotypes worldwide and are particularly concentrated in high-income and upper-middle-income countries, whereas genotypes 3 and 4 are more common in lower-middle and low-income countries. ${ }^{2}$ In the United States, injection drug use represents the primary risk factor for contracting HCV infection. ${ }^{3,4}$ Approximately 15\%-25\% of people acutely infected with HCV will clear the virus, while the remainder will develop chronic infection that can persist largely unnoticed for decades. Indeed, many HCV carriers discover their chronic infection after they have developed cirrhosis. ${ }^{5}$ Chronic HCV infection also is associated with the development of hepatocellular carcinoma, and patients with the disease are more likely to develop cryoglobulinemia and non-Hodgkin's lymphoma. ${ }^{6}$

There is no vaccine currently available for HCV. Before 2011, the standard chronic HCV treatment was a nonspecific antiviral medication using ribavirin combined with pegylated interferon- $\alpha$, which was associated with significant toxicity and limited treatment efficacy. ${ }^{7}$ In 2011, the US Food and Drug Administration approved the firstgeneration of direct-acting antivirals (DAAs) for HCV: boceprevir and telaprevir, both of which inhibit the viral protease (NS3/4A), but required co-treatment with ribavirin and peginterferon. ${ }^{8,9}$ Further approval of more potent DAAs, such as NS3/4A, NS5B, and NS5A inhibitors, led to the development of oral ribavirin/peginterferon-free regimens. ${ }^{5}$ Multi-DAA regimens achieve sustained virologic response (defined as a period of time with no viral RNA detection) rates as high as $100 \%$, and are less toxic and more tolerable than their predecessors. ${ }^{10-13}$ Although the cure rates are remarkable, populations of patients exist who may not benefit from DAA therapy, ${ }^{14}$ especially patients with decompensated cirrhosis resulting from chronic HCV infection, for whom liver transplantation may be a last resort. ${ }^{15}$ Moreover, recurrent infection occurs universally and rapidly after liver transplantation, ${ }^{16,17}$ which increases the risk of accelerated cirrhosis, graft failure, and death. ${ }^{18}$ DAAs, by their nature, cannot prevent recurrent infection. Therefore, alternative or complementary therapies to DAAs that can block viral entry to target cells, such as antibodies or other molecules acting alike, may need to be considered in these circumstances. $^{18,19}$ However, there is currently no entry inhibitor approved for HCV treatment.

The HCV envelope proteins E1 and E2 are heavily glycosylated and, similar to glycoproteins of other enveloped viruses (eg, human immunodeficiency virus [HIV] and the coronaviruses), have a high proportion of high-mannosetype $N$-glycans (HMGs) on their surface. ${ }^{20-22}$ These glycans typically are processed to hybrid and complex forms on glycoproteins secreted by healthy cells. ${ }^{23}$ Thus, the HMGs on the surface of HCV may be considered a druggable target. We previously described the development of an HMGtargeting lectin-Fc fusion protein, or lectibody, called Avaren-Fc (AvFc), which was shown to bind with high affinity to clusters of HMGs on the HIV envelope protein glycoprotein (gp)120 and effectively neutralize multiple HIV clades and groups including HIV-2 and simian immunodeficiency virus. ${ }^{24}$ Further analysis indicated that AvFc can bind to HCV E2 protein. ${ }^{24}$ Therefore, in this study, we aim to investigate the anti-HCV therapeutic potential of AvFc in in vitro neutralization assays and an in vivo HCV challenge study using PXB mice, a chimeric urokinase plasminogen Q15 activator/severe combined immunodeficiency (uPA/SCID) mouse model transplanted with human hepatocytes (reviewed by Tateno and Kojima ${ }^{25}$ ).

\section{Results}

\section{AvFc Shows Broad Anti-HCV Activity In Vitro}

Building on our previous observation that AvFc has affinity to a recombinant HCV E2 envelope protein, ${ }^{24}$ we first examined whether AvFc inhibits HCV infection in vitro using multiple genotypes of cell culture-produced virus (HCVcc) or pseudotyped virus (HCVpp). AvFc significantly blocked the infection of the human liver cell line Huh-7 by HCVcc from genotypes $1 \mathrm{a}, 2 \mathrm{a}, 4 \mathrm{a}, 5 \mathrm{a}$, and $6 \mathrm{a}$, with $50 \%$ inhibitory concentration values in the low nanomolar range (Table 1 and Figure $1 A$ ). Compared with Avaren monomer, AvFc overall showed approximately 2-log higher activity, although no inhibitory effect was observed for the plantproduced anti-HIV broadly neutralizing antibody VRC01, which shares the same human IgG1 Fc region with AvFc. ${ }^{26}$ In addition, Avaren and AvFc, but not VRC01, effectively neutralized HCVpp harboring a murine leukemia virus backbone, suggesting that the lectin and the lectibody act as an entry inhibitor (Figure $1 B$ ).

\section{Formulation of AvFc Into a Biocompatible Buffer for In Vivo Studies}

Previously, we found that AvFc has limited solubility in phosphate-buffered saline (PBS) at concentrations greater than $1 \mathrm{mg} / \mathrm{mL}$ (unpublished observation). To facilitate in vivo studies, we screened for an optimal liquid formulation for systemic administration that can impart improved stability and solubility to AvFc at higher concentrations. Initial buffer screening showed that $A v F c$ is prone to degradation at and below a $\mathrm{pH}$ of 6.5 , suggesting that AvFc is not stable in acidic pH conditions (Figure 2, Table 2). Further preformulation studies led us to identify an optimal buffer composed of $30 \mathrm{mmol} / \mathrm{L}$ histidine, pH 7.0, $100 \mathrm{mmol} /$ $\mathrm{L}$ sucrose, and $100 \mathrm{mmol} / \mathrm{L} \mathrm{NaCl}$. Although AvFc showed comparable melting temperature in the histidine buffer and PBS in differential scanning fluorimetry $\left(62.49^{\circ} \mathrm{C} \pm 0.13^{\circ} \mathrm{C}\right.$

Abbreviations used in this paper: ALT, alanine aminotransferase; AvFc, Avaren-Fc; DAA, direct-acting antiviral; h-Alb, human albumin; HCV, hepatitis C virus; HCVcc, cell-culture-derived hepatitis C virus; HCVpp, hepatitis C virus pseudovirus; HIV, human immunodeficiency virus; HMG, high-mannose glycans; JFH, __ _ PBS, phosphate-buffered saline; RT-PCR, reverse-transcription polymerase chain reaction UPA/SCID, urokinase plasminogen activator/severe combined immunodeficiency.

(C) 2020 The Authors. Published by Elsevier Inc. on behalf of the AGA Institute. This is an open access article under the CC BY license (http://creativecommons.org/licenses/by/4.0/). 2352-345X https://doi.org/10.1016/j.jcmgh.2020.08.009 181 
Table 1. I $\mathrm{C}_{50}$ Values for AvFc and Avaren Against HCVcc

\begin{tabular}{lccr} 
Virus & Genotype & Avaren IC $50, n m o l / L$ & AvFc IC \\
$50, n m o l / L$ \\
\hline JFH1/H77 & $1 a$ & $529.28 \pm 158.78$ & $1.69 \pm 0.39$ \\
JFH1 & $2 a$ & $484.62 \pm 109.16$ & $1.69 \pm 0.78$ \\
JFH1/ED43 & $4 a$ & $204.27 \pm 1.65$ & $2.85 \pm 0.91$ \\
JFH1/SA13 & $5 a$ & $148.86 \pm 2.48$ & $2.33 \pm 0.13$ \\
JFH1/HK6a & $6 a$ & $114.95 \pm 52.93$ & $1.95 \pm 0.78$ \\
& Average & $269.39 \pm 65.00$ & $2.10 \pm 0.60$
\end{tabular}

$\mathrm{IC}_{50}, 50 \%$ inhibitory concentration.

vs $62.68^{\circ} \mathrm{C} \pm 0.25^{\circ} \mathrm{C}$ ) (Figure $3 A$ ), sodium dodecyl sulfate-polyacrylamide gel electrophoresis analysis showed that the lectibody holds superior stability in the histidine buffer upon accelerated stability testing via overnight incubation at $55^{\circ} \mathrm{C}$ (Figure $3 B$ ). When concentrated to approximately $10 \mathrm{mg} / \mathrm{mL}, A v F c$ remained stable in solution in the histidine buffer over 72 hours at $4{ }^{\circ} \mathrm{C}$ and room temperature, while showed a significant concentration decrease concomitant with increasing turbidity in PBS (Figure $3 C$ ), further showing the histidine buffer's superiority for AvFc formulation.

\section{Pharmacologic and Toxicologic Analysis of AvFC in Mice}

To determine an optimal dosing regimen for an HCV challenge experiment, a pharmacokinetic analysis of AvFc was conducted in $\mathrm{C} 57 \mathrm{bl} / 6$ mice. After a single intraperitoneal injection of AvFc at a dose of $25 \mathrm{mg} / \mathrm{kg}$, a peak drug concentration was observed between 2 and 4 hours, with a half-life of 24.5 hours in male animals and 18.5 hours in female animals (Figure 4). After 48 hours, in both male and female animals, the plasma concentration of AvFc remained above a target trough concentration of $130 \mathrm{nmol} /$ $\mathrm{L}(10 \mu \mathrm{g} / \mathrm{mL})$, at which time AvFc showed more than $90 \%$ neutralization effects against HCV (Figure 1). Consequently, these results suggested that administration of the drug every other day might be sufficient to keep the virus under control in a murine HCV challenge model.

We then assessed the safety of every-other-day administration of AvFc in PXB mice. To effectively discern potential toxicity associated with AvFc HMG-binding activity, we included an AvFc variant lacking HMG-binding activity as a control $\left(\mathrm{AvFc}^{\mathrm{lec}^{-}}\right.$) (Figure $5 A$ and $B$ ). PXB mice received either the vehicle (the histidine buffer described earlier) every other day for 11 total doses, AvFc at $25 \mathrm{mg} / \mathrm{kg}$ every

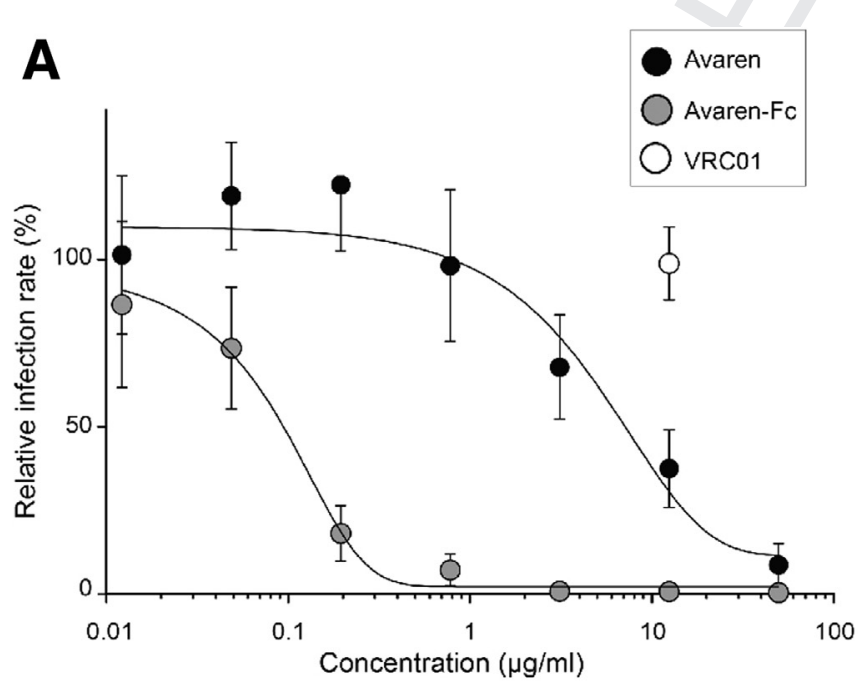

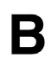

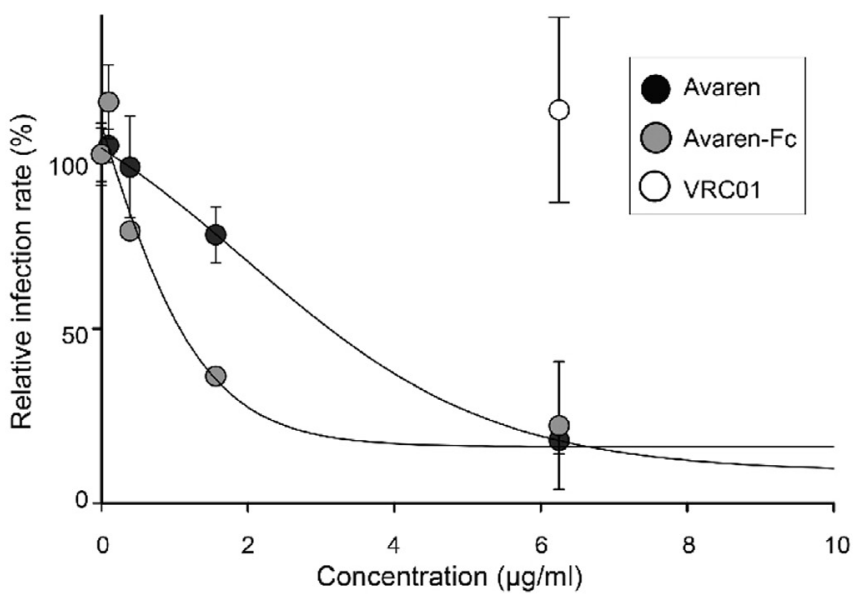

Figure 1. In vitro HCV inhibition assays. $(A)$ Avaren and AvFc inhibit cell-culture derived HCV. The JFH1 virus was preincubated with Avaren, AvFc, or the control antibody VRC01 for 30 minutes at $37^{\circ} \mathrm{C}$ before incubation with Huh-7 cells. At 48 hours after infection, infected cells were quantified by indirect immunofluorescence with an HCV-specific antibody. Results are expressed as a percentage of infection compared with a control infection in the absence of compound. Error bars indicate SEM values from at least 3 independent experiments. $(B)$ Avaren and AvFc inhibit HCV entry. Retroviral pseudotypes bearing $\mathrm{HCV}$ envelope glycoproteins of the JFH1 virus (HCVpp) were preincubated with Avaren, AvFc, or the control antibody VRC01 for 30 minutes at $37^{\circ} \mathrm{C}$ before incubation with Huh-7 cells. At 48 hours after infection, cells were lysed to quantify the luciferase activity. Results are expressed as the percentage of infection compared with the control infection in the absence of compound. Error bars indicate SEM values from at least 3 independent experiments. 

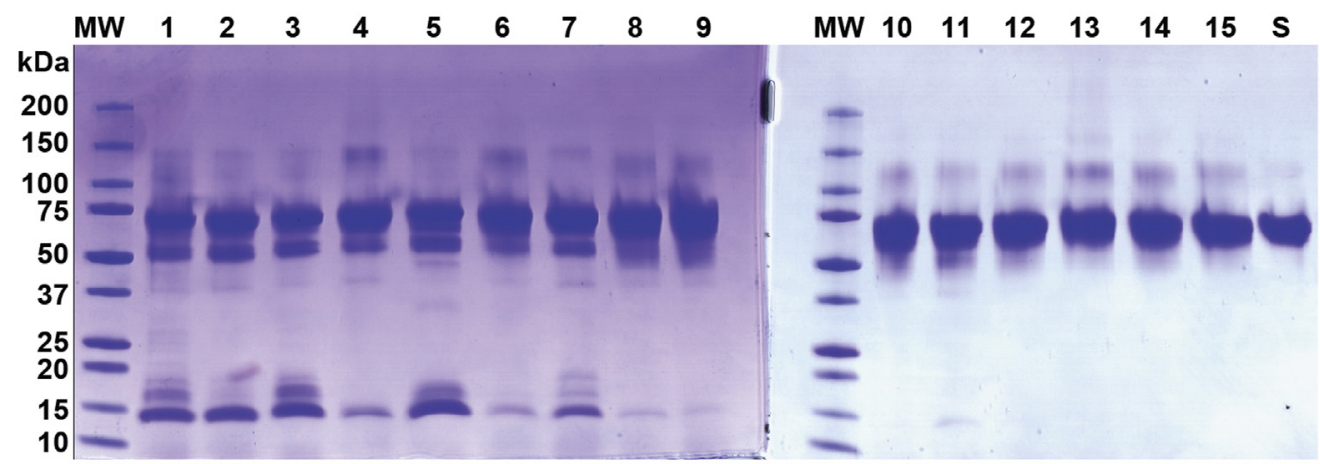

412

413

414

415

416

417

418

419

420

421

422

423

Figure 2. Stability of AvFc in various buffers. The initial buffer screening was performed by incubating $1 \mathrm{mg} / \mathrm{mL}$ of $A v F c$ at $37^{\circ} \mathrm{C}$ for 2 weeks in various buffers without any excipient (listed in Table 2), followed by sodium dodecyl R sulfate-polyacrylamide gel electrophoresis analysis. The image shows a Coomassie Brilliant Blue-stained gel resolving $10 \mu \mathrm{g}$ of AvFc from respective buffers, including glutamate at pH 4.5 (lane 1) and 5.0 (lane 2); acetate at pH 4.5 (lane 3) and 5.5 (lane 4 4); citrate at pH 5.0 (lane 5) and 6.0 (lane 6); succinate at pH 5.5 (lane 7) and 6.5 (lane 8); histidine at pH 6.0 (lane 9) and 7.0 (lane 10); phosphate at pH 6.5 (lane 11), 7.0 (lane 12), and 7.5 (lane 13); Tris at pH 7.5 (lane 14); and PBS (lane 15). At pH 6.0 and less 3 (buffers 1-9), AvFc showed significant degradation after 2 weeks at $37^{\circ} \mathrm{C}$. AvFc did not significantly degrade in buffers $10-15$, and therefore these were chosen for further preformulation analysis. MW, molecular weight marker; S, standard AvFc control.

other day for a total of 8 or 11 doses, or $\mathrm{AvFc}^{\text {lec- }}$ at $25 \mathrm{mg} / \mathrm{kg}$ every other day for 11 total doses. As shown in Figure $6 A-C$, no significant differences in either body weights, blood hAlb levels, or serum alanine aminotransferase (ALT) activity were observed. In addition, no significant differences in relative liver weight were seen (Figure $6 D$ ). These results indicate that $\mathrm{AvFc}$, formulated in the histidine buffer, was well tolerated in the immunocompromised mice engrafted with human hepatocytes.

Histopathology was performed to evaluate any potential toxicity to the human liver grafts resulting from $A v F c$ administration (Table 3 and Figure 7). In the human hepatocyte area, a slight to moderate (scores of 2-3 in Table 2) macrovesicular fatty change, a characteristic change of human hepatocytes in the PXB mouse, was observed in all mice, including the vehicle-treated group (Figure $7 A-C$ ). Minimal inflammatory cell infiltration around vacuolated hepatocytes (score, 1) was seen in 1 mouse each from the 11-dose AvFc and AvFc ${ }^{\text {lec- }}$ groups (Figure $7 D$ and E); however, this was unlikely treatment-related because a similar change is seen occasionally in PXB mice (PhoenixBio, New York, NY) (unpublished observation). No AvFc treatmentspecific change was observed, except for an incidental build-up of pigmentation found in the Glisson's sheath in the liver of 1 mouse (Figure 7F). Collectively, it was concluded that there was no treatment-related adverse effect in the liver tissue. The full pathology report may be found in the Supplementary Information.

Table 2.Buffers Used in the Initial Screening of AvFc Preformulation Analysis

\begin{tabular}{|c|c|c|}
\hline Number & Formulation & $\mathrm{pH}$ \\
\hline 1 & $30 \mathrm{mmol} / \mathrm{L}$ glutamate $\left(5.61 \mathrm{~g} / \mathrm{L} \mathrm{NaOOCCH} \mathrm{CH}_{2} \mathrm{CH}\left(\mathrm{NH}_{2}\right) \mathrm{COOH} \times \mathrm{H}_{2} \mathrm{O}\right)^{2}$ & 4.5 \\
\hline 2 & $30 \mathrm{mmol} / \mathrm{L}$ glutamate $\left(5.61 \mathrm{~g} / \mathrm{L} \mathrm{NaOOCCH} \mathrm{CH}_{2} \mathrm{CH}\left(\mathrm{NH}_{2}\right) \mathrm{COOH} \times \mathrm{H}_{2} \mathrm{O}\right)^{a}$ & \\
\hline 3 & $30 \mathrm{mmol} / \mathrm{L}$ acetate $\left(2.46 \mathrm{~g} / \mathrm{L} \mathrm{CH}_{3} \mathrm{COONa}\right)^{2}$ & \\
\hline 4 & $30 \mathrm{mmol} / \mathrm{L}$ acetate $\left(2.46 \mathrm{~g} / \mathrm{L} \mathrm{CH}_{3} \mathrm{COONa}\right)^{a}$ & \\
\hline 5 & $30 \mathrm{mmol} / \mathrm{L}$ citrate $\left(350 \mathrm{~mL} 0.1 \mathrm{~mol} / \mathrm{L} \mathrm{C}_{6} \mathrm{H}_{8} \mathrm{O} 7 \times \mathrm{H}_{2} \mathrm{O}, 650 \mathrm{~mL} 0.1 \mathrm{~mol} / \mathrm{L} \mathrm{C}_{6} \mathrm{H}_{5} \mathrm{O}_{7} \mathrm{Na}_{3} \times 2 \mathrm{H}_{2} \mathrm{O}\right)$ & \\
\hline 6 & $30 \mathrm{mmol} / \mathrm{L}$ citrate $\left(115 \mathrm{~mL} 0.1 \mathrm{~mol} / \mathrm{L} \mathrm{C}_{6} \mathrm{H}_{8} \mathrm{O} \times \mathrm{H}_{2} \mathrm{O}, 885 \mathrm{~mL} 0.1 \mathrm{~mol} / \mathrm{L} \mathrm{C}_{6} \mathrm{H}_{5} \mathrm{O}_{7} \mathrm{Na}_{3} \times 2 \mathrm{H}_{2} \mathrm{O}\right)$ & \\
\hline 7 & $30 \mathrm{mmol} / \mathrm{L}$ succinate $\left(4.86 \mathrm{~g} / \mathrm{L} \mathrm{NaOOCCH} \mathrm{CH}_{2} \mathrm{COONa}\right)^{2}$ & \\
\hline 8 & $30 \mathrm{mmol} / \mathrm{L}$ succinate $\left(4.86 \mathrm{~g} / \mathrm{L} \mathrm{NaOOCCH} \mathrm{CH}_{2} \mathrm{COONa}\right)^{a}$ & \\
\hline 9 & $30 \mathrm{mmol} / \mathrm{L}$ histidine $\left(4.65 \mathrm{~g} / \mathrm{L} \mathrm{C}_{6} \mathrm{H}_{9} \mathrm{~N}_{3} \mathrm{O}_{2}\right)^{2}$ & \\
\hline 10 & $30 \mathrm{mmol} / \mathrm{L}$ histidine $\left(4.65 \mathrm{~g} / \mathrm{L} \mathrm{C}_{6} \mathrm{H}_{9} \mathrm{~N}_{3} \mathrm{O}_{2}\right)^{a}$ & \\
\hline 11 & $30 \mathrm{mmol} / \mathrm{L}$ phosphate $\left(2.89 \mathrm{~g} / \mathrm{L} \mathrm{NaH}{ }_{2} \mathrm{PO}_{4} \times \mathrm{H}_{2} \mathrm{O}, 2.42 \mathrm{~g} \mathrm{Na}_{2} \mathrm{HPO}_{4} \times 7 \mathrm{H}_{2} \mathrm{O}\right)$ & \\
\hline 12 & $30 \mathrm{mmol} / \mathrm{L}$ phosphate $\left(1.75 \mathrm{~g} / \mathrm{L} \mathrm{NaH}{ }_{2} \mathrm{PO}_{4} \times \mathrm{H}_{2} \mathrm{O}, 4.64 \mathrm{~g} \mathrm{Na}_{2} \mathrm{HPO}_{4} \times 7 \mathrm{H}_{2} \mathrm{O}\right)$ & \\
\hline 13 & $30 \mathrm{mmol} / \mathrm{L}$ phosphate $\left(0.78 \mathrm{~g} / \mathrm{L} \mathrm{NaH} \mathrm{PO}_{4} \times \mathrm{H}_{2} \mathrm{O}, 6.53 \mathrm{~g} \mathrm{Na}_{2} \mathrm{HPO}_{4} \times 7 \mathrm{H}_{2} \mathrm{O}\right)$ & \\
\hline 14 & $30 \mathrm{mmol} / \mathrm{L}$ Tris $\left(3.63 \mathrm{~g} / \mathrm{L} \mathrm{NH}_{2} \mathrm{C}\left(\mathrm{CH}_{2} \mathrm{OH}\right)_{3}\right)^{a}$ & \\
\hline 15 & PBS $\left(0.144 \mathrm{~g} / \mathrm{L} \mathrm{KH}_{2} \mathrm{PO}_{4}, 9 \mathrm{~g} / \mathrm{L} \mathrm{NaCl}, 0.795 \mathrm{~g} / \mathrm{L} \mathrm{Na}{ }_{2} \mathrm{HPO}_{4}\right)$ & \\
\hline
\end{tabular}



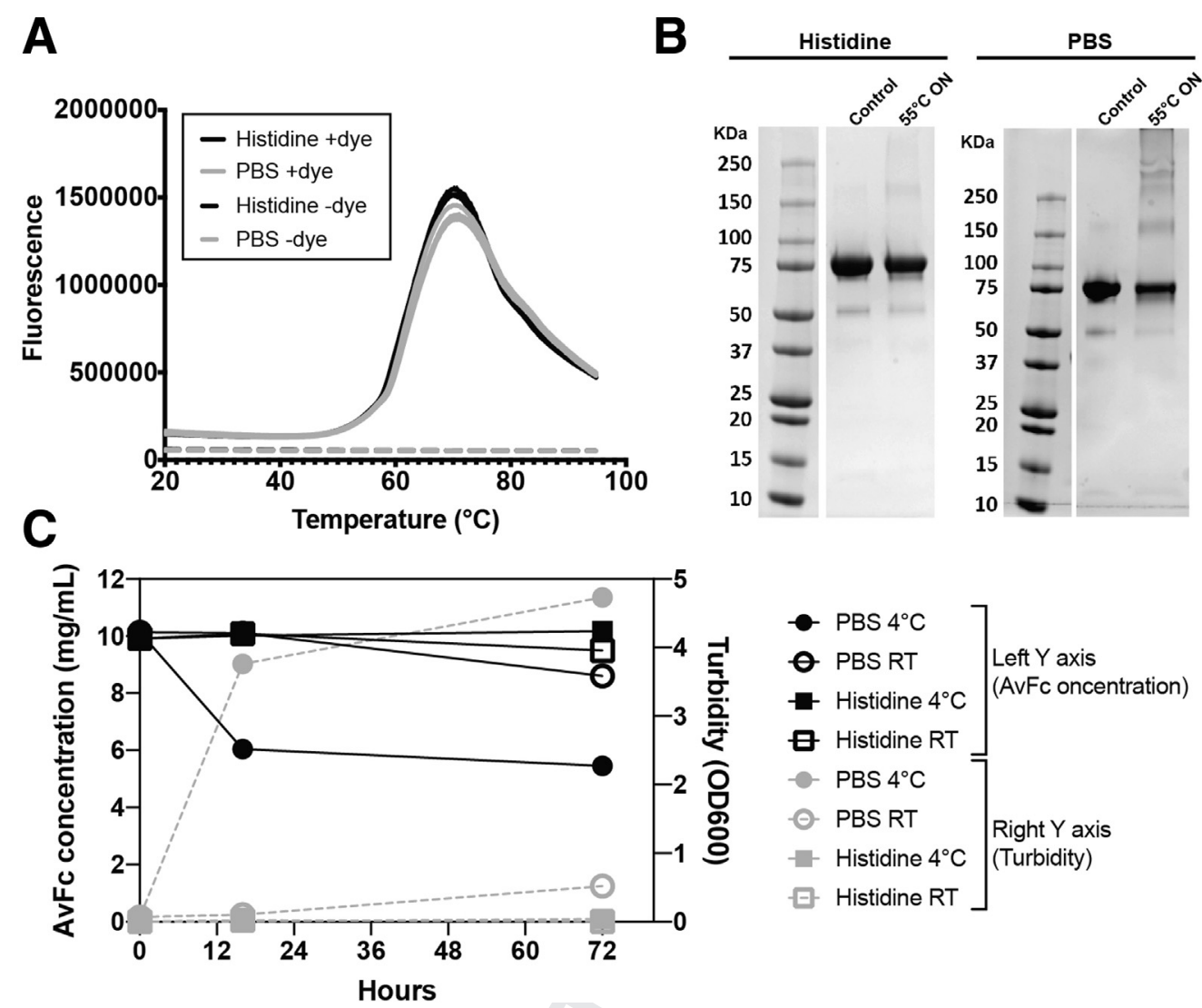

530

531

532

533

534

535

536

537

538

539

540

541

542

543

544

545

546

547

548

549

550

551

552

553

554

555

556

557

558

Figure 3. Liquid formulation development for AvFc. (A) Differential scanning fluorimetry for melting temperature measurement. AvFc was prepared in $30 \mathrm{mmol} / \mathrm{L}$ histidine buffer, $100 \mathrm{mmol} / \mathrm{L} \mathrm{NaCl}, 100 \mathrm{mmol} / \mathrm{L}$ sucrose (histidine, black line), or PBS (grey line) at a concentration of $1 \mathrm{mg} / \mathrm{mL}$ and analyzed in triplicate in the presence (solid line) or absence (dashed line) of the fluorescent dye SYPRO Orange. Melting temperature values were $62.49^{\circ} \mathrm{C} \pm 0.13^{\circ} \mathrm{C}$ in the histidine buffer and $62.68^{\circ} \mathrm{C} \pm{ }^{\circ}$ $0.25^{\circ} \mathrm{C}$ in PBS, as determined by the vertex of the first derivative of the relative fluorescence unit values. $(B)$ Accelerated stability testing of AvFc in the histidine buffer and PBS. AvFc, prepared at $1 \mathrm{mg} / \mathrm{mL}$ in the histidine buffer or PBS were incubated overnight at $55^{\circ} \mathrm{C}$, and $10 \mu \mathrm{g}$ of the protein from each formulation was analyzed by sodium dodecyl sulfate-polyacrylamide gel electrophoresis under nonreducing conditions. A representative Coomassie-stained gel image is shown. The band at around 75 kilodaltons corresponds to AvFc. Note that after overnight incubation, PBS shows less band intensity for AvFc and more large-size aggregate bands than the histidine buffer. $(C)$ Time course of concentration change and the turbidity of AvFc solution in the histidine buffer and PBS. AvFc was formulated at $10 \mathrm{mg} / \mathrm{mL}$ in respective buffers and incubated at $4{ }^{\circ} \mathrm{C}$ or room temperature (RT). After 16 and 72 hours, the concentration was measured using a theoretical extinction coefficient at $280 \mathrm{~nm}$ of $1.6493\left(\mathrm{mg} / \mathrm{mL}^{-1} \mathrm{~cm}^{-1}\right.$, whereas turbidity was assessed by absorbance at $600 \mathrm{~nm}$. Representative data are shown for samples analyzed in triplicate.

\section{AvFc Protects Against HCV Infection In Vivo}

Lastly, we assessed the protective efficacy of AvFc against HCV infection in vivo using the treatment regimen described earlier. PXB mice were inoculated intraperitoneally with a genotype $1 \mathrm{a}$ virus along with initial treatment with $25 \mathrm{mg} / \mathrm{kg}$ of AvFc or AvFc ${ }^{\text {lec- }}$ on day 0. As shown in Figure $8 A, A v F c^{\text {lec- }}$-treated mice showed high serum HCV RNA levels from day 7 after challenge through the end of the study on day 35. In sharp contrast, animals treated with both 8 and 11 doses of AvFc did not show any quantifiable level $\left(4.0 \times 10^{4}\right.$ copies $\left./ \mathrm{mL}\right)$ of HCV RNA in sera, indicating that the lectibody prevented the infection of human liver grafts by the virus. Similar to the results in Figure 3, overall no major toxicity signal was noted in body weights, human albumin (h-Alb), or h-ALT levels between the test groups, although there was a temporal decrease in body weight and
h-Alb in 1 of the AvFc-treated groups at an early time point, indicating that the liver grafts remained functional over the course of the study (Figure $8 B-D$ ).

\section{Discussion}

In this study we showed that the HMG-binding lectibody AvFc shows broad genotype-independent anti-HCV activity. In addition, systemic administration of AvFc effectively protected chimeric human-mouse liver mice from infection with a genotype 1a virus without apparent toxicity, providing in vivo proof-of-concept for the lectibody's anti- Q20584 viral potential.

The mechanism of HCV neutralization by AvFc likely is through binding to HMGs on the E1/E2 envelope protein dimer, which blocks their interaction with host cell 
589

590

591

592

593

594

595

596

597

598

599

600

601

602

603

604

605

606

607

608

609

610

611

612

613

614

615

616

617

618

619

620

621

622

623

624

625

626

627

628

629

630

631

632

633

634

635

636

637

638

639

640

641

642

643

644

645

646

647

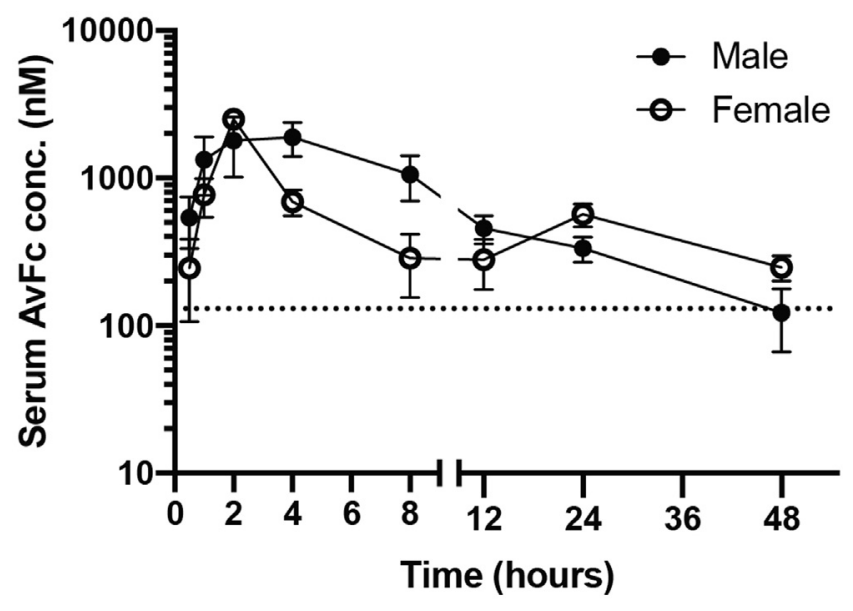

Figure 4. Pharmacokinetics of AvFc in mice. AvFc pharmacokinetics were evaluated in $\mathrm{C} 57 \mathrm{bl} / 6$ mice after a single intraperitoneal injection of $25 \mathrm{mg} / \mathrm{kg}$ with blood sampled at various time points. Data are expressed as means \pm SEM from 4 mice per group. The average half-life was 24.5 and 18.5 hours in male and female mice, respectively, as determined by the PKSolver Microsoft Excel Add-on. The peak concentration occurred between 2 and 4 hours after administration. The target trough concentration of $130 \mathrm{nmol} / \mathrm{L}$ (corresponding to $10 \mu \mathrm{g} / \mathrm{mL}$ ) is indicated by a dashed line.

receptors and viral entry. Unlike HIV envelope glycoproteins, whose glycan content can vary widely between strains, the number and position of glycosylation sites on E1/E2 are highly conserved, indicating their critical role in HCV's infectious processes. ${ }^{27}$ The notion that AvFc functions as an entry inhibitor is supported by the fact that the lectibody has affinity to the E2 protein ${ }^{24}$ and that other mannose-binding lectins, such as Griffithsin or Cyanovirin$\mathrm{N}$, inhibit entry in this manner. ${ }^{28,29}$ AvFc inhibited multiple genotypes of HCV with average $50 \%$ inhibitory concentrations more than 100 -fold lower than that of the monomer Avaren lectin (Table 1), indicating that the multivalent recognition of HMGs on the surface of the virus, brought about by the dimerization of Avaren via Fc fusion, led to greater entry inhibition. Unlike other antiviral lectins, however, the inclusion of the human IgG1 Fc region implicates the possibility of Fc-mediated effector functions, such as antibody-dependent cell-mediated cytotoxicity, against infected cells. In fact, Fc-mediated effector functions greatly contributed to the antiviral potency of AvFc against HIV, as determined by a primary cell-based inhibition assay and an antibody-dependent cell-mediated viral inhibition assay. ${ }^{24}$ Accordingly, the remarkable efficacy seen in the present in vivo HCV challenge study may be partially Fc-mediated. Further investigations are necessary to address this possibility.

The present study also showed that AvFc therapy is well tolerated in mice and human hepatocytes because everyother-day intraperitoneal administration of $25 \mathrm{mg} / \mathrm{kg}$ AvFc, of up to 11 doses, did not show any obvious toxicity in PXB mice by gross necropsy or histopathology of engrafted human hepatocytes, and it did not result in significant changes in body weight, h-Alb level, or ALT level (Figures 6 and 7). This corroborates our previous observation that AvFc administration, both intraperitoneally and intravenously, was well tolerated and produced no toxicity in mice, rats, or rhesus macaques. ${ }^{24}$ We hypothesize that the lack of any significant toxicity is attributable to the unique HMGbinding mechanism of AvFc, whereby it requires multivalent interaction with several HMGs in proximity to show high-affinity binding to a glycoprotein target. In line with this hypothesis, Hoque et $\mathrm{al}^{30}$ showed that the 3 binding pockets of the parent lectin actinohivin can bind up to 3 independent HMGs, providing high-affinity binding when the HMGs are in relatively close proximity. This implies that AvFc may not interact effectively with healthy normal cells and tissues that do not usually show clusters of HMGs on their surfaces. In contrast, glycoproteins of many enveloped viruses show a high proportion of these immature forms of $N$-glycans. ${ }^{20-22}$ Although HCV E2 has fewer $N$-glycosylation sites (approximately 11) than the HIV gp120 (which has between 20 and 30, depending on the strain), E2 likely is present on the surface of HCV at a higher density and thus provides higher local concentrations of HMGs. ${ }^{31}$ Further studies are necessary to show a threshold HMG concentration that enables efficient interaction between $\mathrm{AvFc}$ and the surfaces of cells or viruses.

Although alcoholic liver disease has now surpassed HCV infection as the number one indication for liver transplantation in the United States, a large number of procedures will continue to be performed for the foreseeable future in patients with HCV-related decompensated cirrhosis. ${ }^{32}$ A major outstanding issue is the lack of effective treatment protecting the allograft liver from recurrent infection by the virus that remained circulating in the periphery at the time of transplant. As a consequence, reinfection of donor livers occurs universally, as early as in the first 90 minutes of reperfusion, ${ }^{17}$ and can result in accelerated fibrosis and increased risk of graft failure, cirrhosis, and hepatocellular carcinoma. ${ }^{33}$ In fact, allograft failure resulting from re-infection is the leading cause of secondary transplants and death in HCV-infected patients who have received a liver transplant. ${ }^{34}$ Patients cured of HCV with DAAs after liver transplantation still have a higher-than-normal risk of hepatocellular carcinoma, ${ }^{35}$ and the high cost of the drugs represents a significant barrier to their widespread use. Furthermore, emergent drug resistance, even in DAA combination therapies, although rare, represents a particular challenge for further treatment. ${ }^{36}$ Unlike DAAs, entry inhibitors neutralize circulating viruses and physically block the viral infection of target cells. The use of entry inhibitors perioperatively upon liver transplantation, either alone or in combination with DAAs, may improve treatment outcomes significantly. ${ }^{34,37}$ Thus, although the effectiveness of DAAs is not in question, there still are unmet needs that may be addressed through the use of entry inhibitors.

To date, no entry inhibitor has been approved for the treatment or prevention of HCV. Two major drug candidates, Civacir and MBL-HCV1, have shown some promise in ${ }^{2}$ clinical trials (NCT01804829 and NCT01532908). ${ }^{38,39}$ Although larger studies are needed, it appears that entry
648

649

650

651

652

653

654

655

656

657

658

659

660

661

662

663

664

665

666

667

668

669

670

671

672

673

674

675

676

677

678

679

680

681

682

683

684

685

686

687

688

689

690

691

692

693

694

695

696

697

698

699

700

701

702

703

21704

705

706 


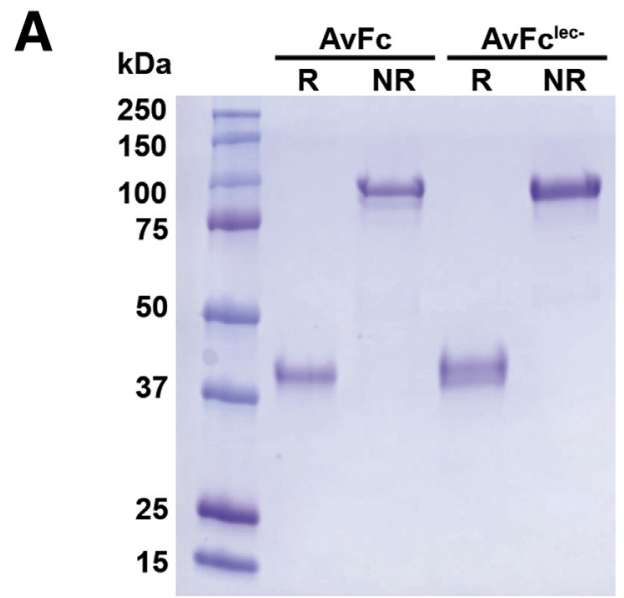

766

767

768

769

\section{AvFclec-}
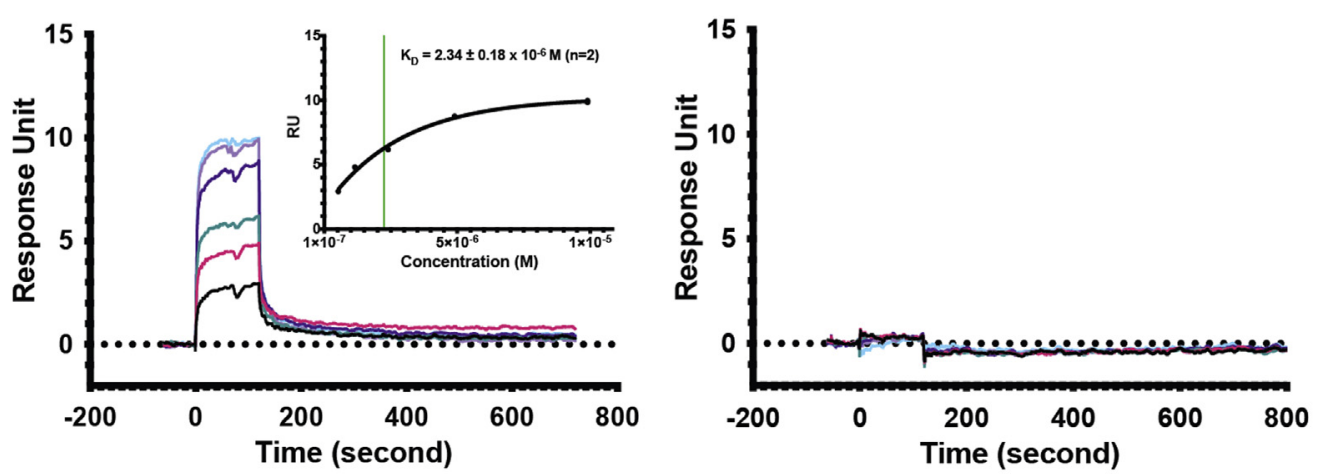

783

784

785

786

787

788

789

790

791

792

793

794

795

796

797

798

799

800 (NR) conditions. Under R conditions, AvFc monomer is seen at 38.5 kilodaltons; under NR conditions, AvFc dimer (via 800
interpolypeptide disulfide bonds in the Fc region) appears at 77 kilodaltons. (B) Surface plasmon resonance analysis of HCV 801 E2-binding affinity of AvFc and AvFclec-. A recombinant E2 protein (Immune Technology Corp) was immobilized to a CM5 chip $\frac{\mathrm{L}}{\mathrm{U}}$ using amine coupling to a surface density of approximately 200 response units (RU). AvFc or AvFc ${ }^{\text {lec- }}$ then was injected over F the chip surface at a rate of $30 \mu \mathrm{L} / \mathrm{min}$ for 120 seconds, followed by a 600 -second dissociation period, with concentrations o ranging from 10 to $0.625 \mu \mathrm{mol} / \mathrm{L}$. Binding affinity was calculated using steady-state analysis and was determined to be $2.34 \pm$ $\$ 0.18 \times 10^{-6} \mathrm{~mol} / \mathrm{L}(2.34 \pm 0.18 \mu \mathrm{mol} / \mathrm{L})$ for AvFc. Binding affinity could not be determined for AvFc ${ }^{\text {lec- }}$ because of the lack of measurable binding.

inhibitors in combination with DAAs may represent a new treatment paradigm for HCV patients receiving a liver transplant. Despite both MBL-HCV1 and Civacir being capable of neutralizing a broad range of HCV genotypes, viral resistance still can develop through mutations in the envelope proteins E1/E2, in particular through shifting glycan positions. ${ }^{40,41}$ In this regard, AvFc in its own right could be less susceptible to amino acid mutations because it targets the glycan shield of the virus rather than a specific epitope. Deletions of glycans, even if occurring after prolonged exposure to a carbohydrate-binding agent such as AvFc, may result in a significant decrease in viral fitness by decreasing E1/E2 incorporation into HCV particles or increased susceptibility to humoral immunity resulting from a breach in the glycan shield. ${ }^{27,42}$ Our results provide a foundation to test the earlier-described hypotheses and feasibility of the HMG-targeting anti-HCV strategy. Of note, a unique advantage of AvFc over the 2 antibody-based entry inhibitor candidates described earlier is that the lectibody has the capacity to neutralize both HIV ${ }^{24}$ and HCV (present study). Accordingly, AvFc may provide an effective means (eg, pre-exposure prophylaxis) to protect high-risk populations against HIV/HCV co-infection, such as health care workers and injection drug users. ${ }^{43,44}$

In conclusion, the present study provides an important proof of concept for the therapeutic potential of $\mathrm{AvFc}$ against HCV infection via targeting envelope HMGs. In particular, the lectibody may provide a safe and efficacious means to prevent recurrent infection on liver transplantation in HCV-related end-stage liver disease patients. Other potential utilities of $\mathrm{AvFc}$ may be found in pre-exposure prophylaxis against HIV/HCV co-infection in 

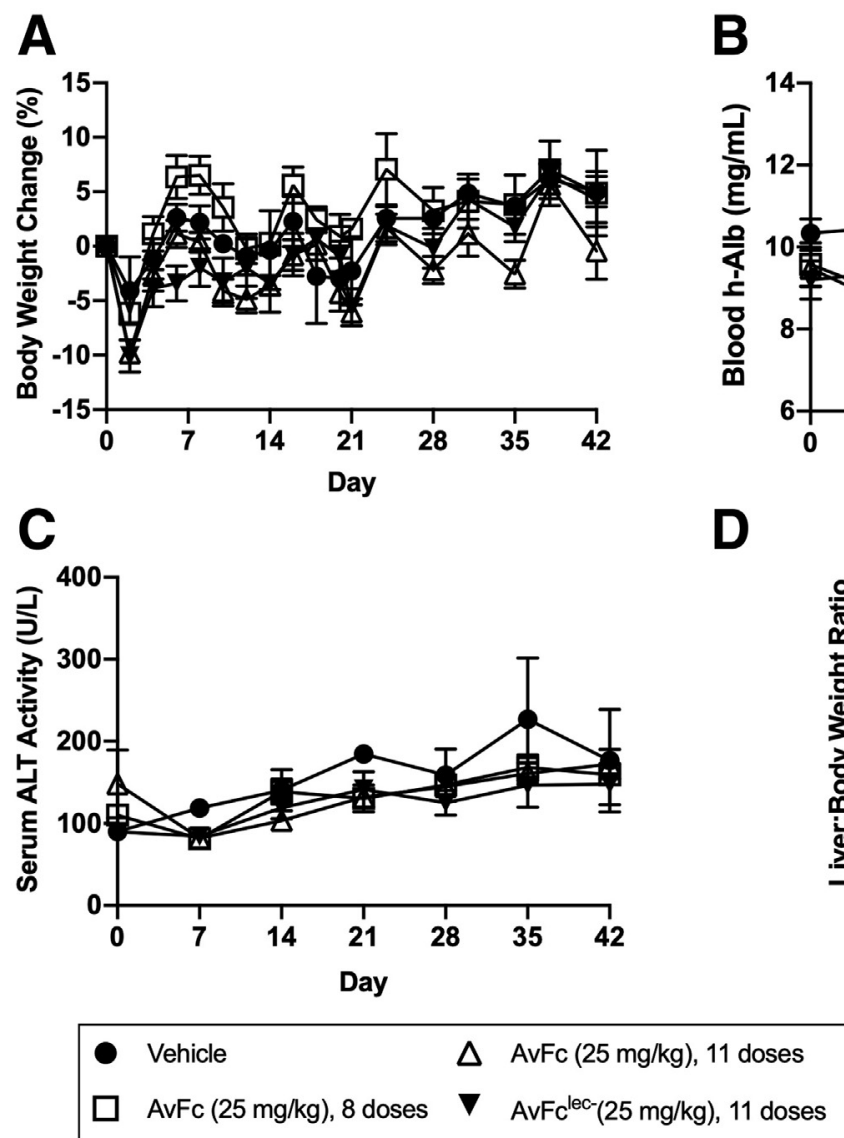

high-risk populations, as well as in the context of transplantation of organs from HCV-infected donors to HCVnegative recipients, which may help alleviate the severe shortage of donor organs available for transplantation. ${ }^{45,46}$ Further studies are warranted to determine a doseresponse relationship, therapeutic window, and feasibility of intravenous or subcutaneous dosing routes, as well as to assess the efficacy of AvFc against established infection.
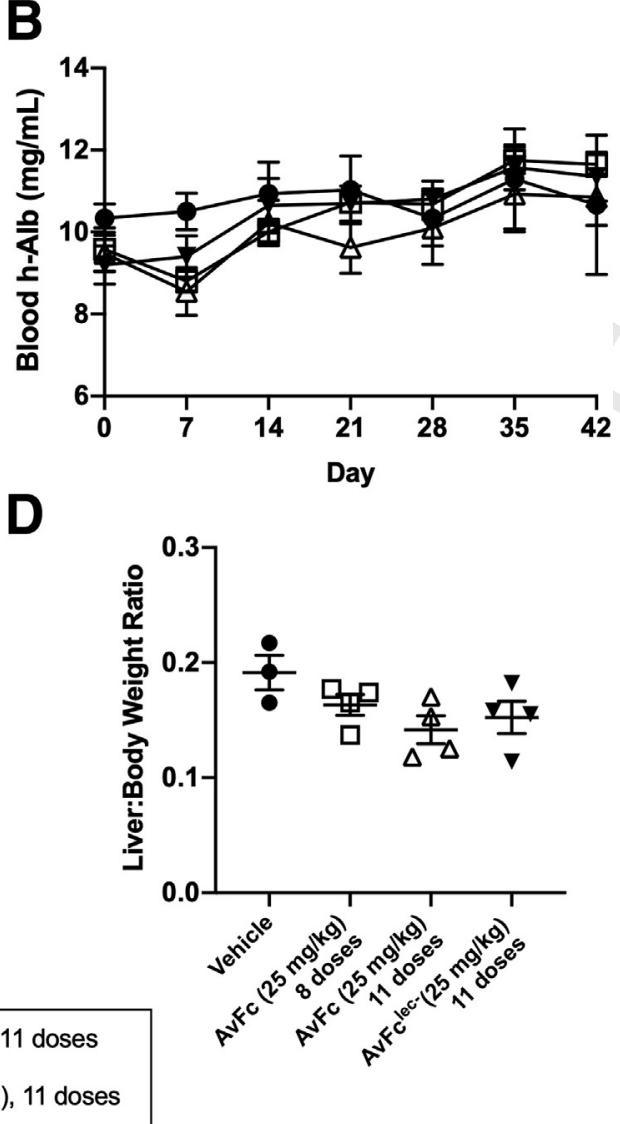

Figure 6. Toxicologic analysis of systemically administered AvFc in the PXB human liver chimeric mouse model. PXB mice were administered $\mathrm{AvFc}$ or $\mathrm{AvFc} \mathrm{Cc}^{\mathrm{le}-}$ intraperitoneally at $25 \mathrm{mg} /$ $\mathrm{kg}$ ( $\mathrm{n}=4$ each), or the histidine buffer vehicle control $(n=3)$ every 2 days and monitored for body weight, blood h-Alb level, and serum alanine ALT level over 42 days. $(A)$ Percentage change of body weights from the initial day of dosing (day 0 ). (B) Blood h-Alb levels. (C) Serum ALT levels. $(D)$ Ratio of liver weight to body weight of individual mice at necropsy. $(A-C)$ Each data point represents means \pm SEM and (D) individual data with means \pm SEM in each group. No significant changes in any of the safety end points were noted between the groups $(A-C, 2$-way analysis of variance; $D, 1$-way analysis of variance).

\section{Table 3. Histopathology of Chimeric Mouse Liver Tissue}

\section{Materials and Methods}

\section{Animal Care}

The use of animals was approved by the University of Louisville's Institutional Animal Care and Use Committee and the Animal Ethics Committee of PhoenixBio Company, Ltd (resolution 2281). All animals were given a standard diet and water ad libitum and were housed in a temperature- and humidity-controlled facility with a 12-hour day/ night cycle.

\begin{tabular}{|c|c|c|c|c|c|c|c|c|c|c|c|c|c|c|c|}
\hline & \multicolumn{3}{|c|}{ Vehicle } & \multicolumn{4}{|c|}{ AvFc ${ }^{l e c-}$} & \multicolumn{4}{|c|}{ AvFc, 11 doses } & \multicolumn{4}{|c|}{ AvFc, 8 doses } \\
\hline & 101 & 102 & 103 & 201 & 202 & 203 & 204 & 301 & 302 & 303 & 304 & 401 & 402 & 403 & 404 \\
\hline Mouse hepatocytes & 0 & 0 & 0 & 0 & 0 & 0 & 0 & 0 & 0 & 0 & 0 & 0 & 0 & 0 & 0 \\
\hline $\begin{array}{l}\text { Human hepatocytes } \\
\text { Fatty change, macrovesicular }\end{array}$ & 2 & 3 & 3 & 3 & 3 & 3 & 3 & 3 & 3 & 3 & 3 & 3 & 3 & 3 & 3 \\
\hline $\begin{array}{l}\text { Infiltrate, inflammatory cell, around } \\
\text { vacuolated hepatocyte }\end{array}$ & 0 & 0 & 0 & 0 & 1 & 0 & 0 & 0 & 1 & 0 & 0 & 0 & 0 & 1 & 0 \\
\hline Portal canal and others & & & & & & & & & & & & & & & \\
\hline $\begin{array}{l}\text { Hepatocellular carcinoma, trabecular, } \\
\text { with extramedullary hematopoiesis }\end{array}$ & $P$ & 0 & 0 & 0 & 0 & 0 & 0 & 0 & 0 & 0 & 0 & 0 & 0 & 0 & 0 \\
\hline Metaplasia, osseous & 0 & 2 & 0 & 0 & 0 & 0 & 0 & 0 & 0 & 0 & 0 & 0 & 0 & 0 & 0 \\
\hline $\begin{array}{l}\text { Pigmentation, brown, histiocyte, Glisson } \\
\text { sheath, focal }\end{array}$ & 0 & 0 & 0 & 0 & 0 & 0 & 0 & 0 & 0 & 0 & 0 & 1 & 0 & 0 & 0 \\
\hline
\end{tabular}

884

885

886

887

888

889

890

891

892

893

894

895

896

897

898

899

900

901

902

903

904

905

906

907

908

909

910

911

912

913

914

915

916

917

918

919

920

921

922

923

924

925

926

927

928

929

930

931

932

933

934

935

936

937

938

939

940 

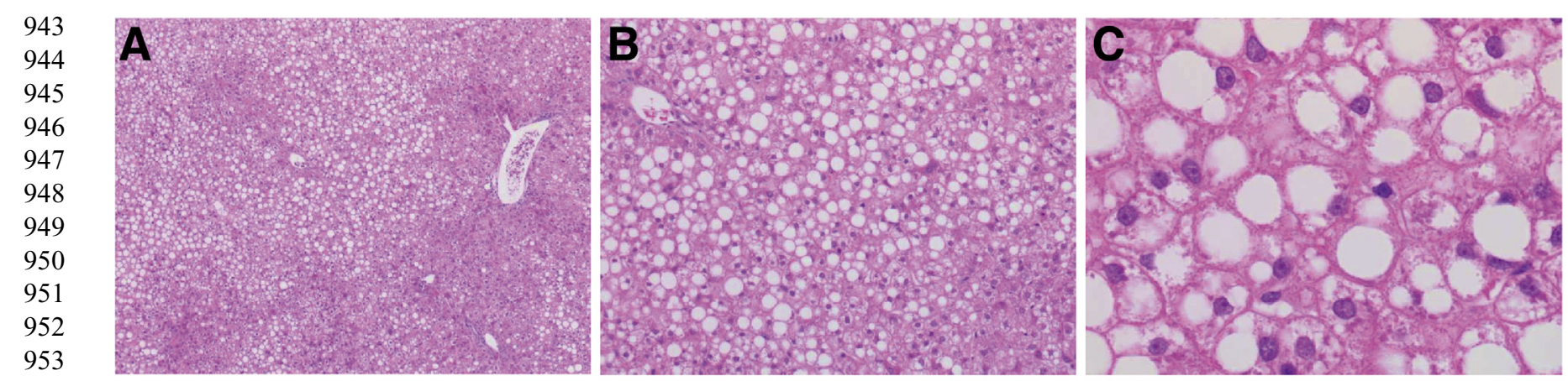

1002

1003

1004

1005

1006

1007

1008

1009

1010

1011

1012

954

955

956

957

958

959

960
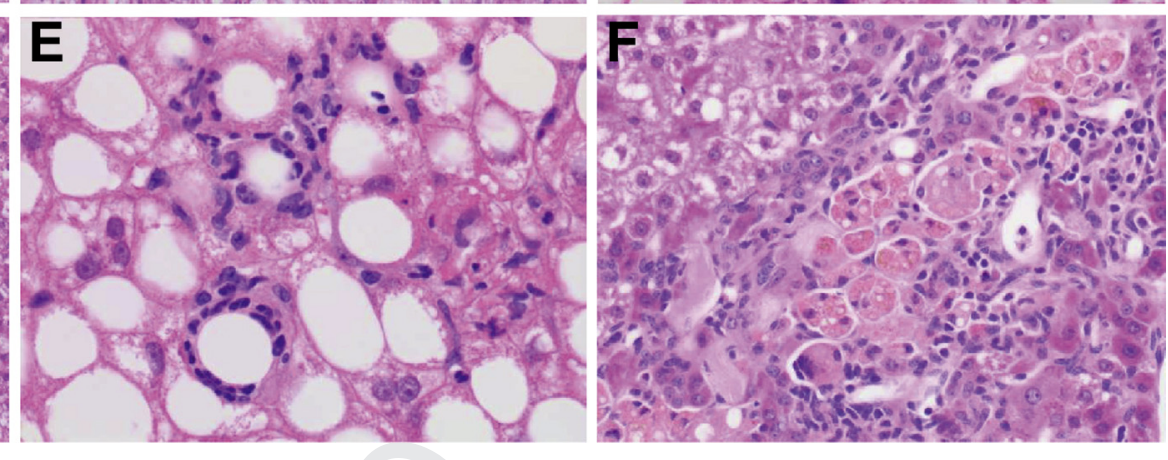

1013

1014

1015

1016

1017

1018

1019

1020

1021

1022

1023

1024

Figure 7. Histopathologic examination of PXB mouse liver tissues. Representative H\&E-stained liver tissue section images corresponding to histopathologic findings in Table 2 are shown. Liver tissues are from the toxicologic study in Figure 4 . ( $A$ ) $A$ $4 \times$ image from an animal in the vehicle control group (mouse ID: 103 in Table 2) showing low magnification of vacuolated hepatocytes. (B) A $10 \times$ image from a portion of panel $A$, containing many human hepatocytes with a large, well-defined, rounded vacuole. $(C)$ Higher magnification $(40 \times)$ of panel $B$. (D) A $10 \times$ image from an animal in the AvFc ${ }^{\text {lec- }}$ group (ID: 202 in Table 2), showing small foci of inflammatory cell inflammation in the human hepatocyte area. $(E)$ Higher magnification $(40 \times)$ of panel $D$. Inflammatory cells appear to surround vacuolated hepatocytes. $(F)$ A $20 \times$ image from an animal in the AvFc group (8 total doses; ID: 401 in Table 2). Histiocytic brown pigmentation in the Glisson sheath was noted only in this mouse.

\section{Production of AvFc and Non-HMG-Binding AvFC Variant}

AvFc and $\mathrm{AvFc}^{\text {lec- }}$ were produced by agroinfiltration with magnICON vectors in Nicotiana benthamiana plants as previously described. ${ }^{24}$ AvFc was purified from plants after a 7-day incubation period using protein A and ceramic hydroxyapatite chromatography.

\section{HCV Neutralization Assays}

Huh-7 cells ${ }^{47}$ and HEK-293T cells (American Type Culture Collection, Manassas, VA) were cultured in Dulbecco's modified Eagle medium supplemented with 10\% heat-inactivated fetal calf serum and 1\% penicillin/streptomycin. To produce HCVcc, we used a modified version of the plasmid encoding JFH1 genome (genotype 2a), provided by T. Wakita (National Institute of Infectious Diseases, Tokyo, Japan). ${ }^{48,49}$ The H77/JFH1 chimera, which expresses the core-NS2 segment of the genotype 1a polyprotein within a genotype 2 a background, has been described previously. ${ }^{50}$ The genotype 4a ED43/JFH1, genotype $5 \mathrm{a} \mathrm{SA} 13 / \mathrm{JFH} 1,{ }^{52}$ and genotype $6 \mathrm{a} \mathrm{HK} 6 \mathrm{a} / \mathrm{JFH} 1^{53}$ infectious HCV recombinants were provided by J. Bukh (University of Copenhagen, Copenhagen, Denmark). Retroviral pseudotypes bearing $\mathrm{HCV}$ envelope glycoproteins of JFH1 virus (HCVpp) expressing the Firefly luciferase reporter gene were produced in HEK-293T as previously described. ${ }^{54}$ Inhibitory effects were determined by quantifying infectivity by indirect immunofluorescence with the anti-E1 monoclonal antibody $\mathrm{A4}^{55}$ or an anti-NS5A polyclonal antibody kindly provided by M. Harris (University of Leeds, Leeds, UK).

\section{Formulation Buffer Optimization}

Initial buffer screening was performed in $30 \mathrm{mmol} / \mathrm{L}$ glutamate, acetate, citrate, succinate, histidine, and phosphate buffers at $\mathrm{pH}$ 4.5-7.5 (Table 2). All the buffer agents were purchased from MilliporeSigma. AvFc was diafiltrated and adjusted to $1 \mathrm{mg} / \mathrm{mL}$ (or $62.5 \mu \mathrm{mol} / \mathrm{L}$ ) in respective buffers. Stability was evaluated by sodium dodecyl sulfate-polyacrylamide gel electrophoresis after incubation for 2 weeks at $37^{\circ} \mathrm{C}$. The melting temperatures of AvFc were determined by differential scanning fluorimetry performed on an Applied Biosystems StepOnePlus reversetranscription polymerase chain reaction (RT-PCR) system as described previously. ${ }^{24}$ Briefly, AvFc formulated in various buffers at a concentration of $50 \mu \mathrm{mol} / \mathrm{L}$ was mixed with a final concentration of $50 \times$ SYPRO Orange (S6651; ThermoFisher Scientific) in a 96-well template. The melting temperature was determined by the vertex of the first derivative of the relative fluorescence unit values in the melt curves. AvFc formulated into the optimized histidine buffer or PBS then was concentrated to $10 \mathrm{mg} / \mathrm{mL}$ and incubated
1025

1026

1027

1028

1029

1030

1031

1032

1033

1034

1035

1036

1037

1038

1039

1040

1041

1042

1043

1044

261045

1046

1047

1048

1049

1050

1051

1052

1053

1054

1055

1056

1057

1058

1059

1060 
A

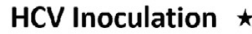

AvFc, 8 doses $\square$

AvFc, 11 doses $\Delta$

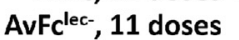
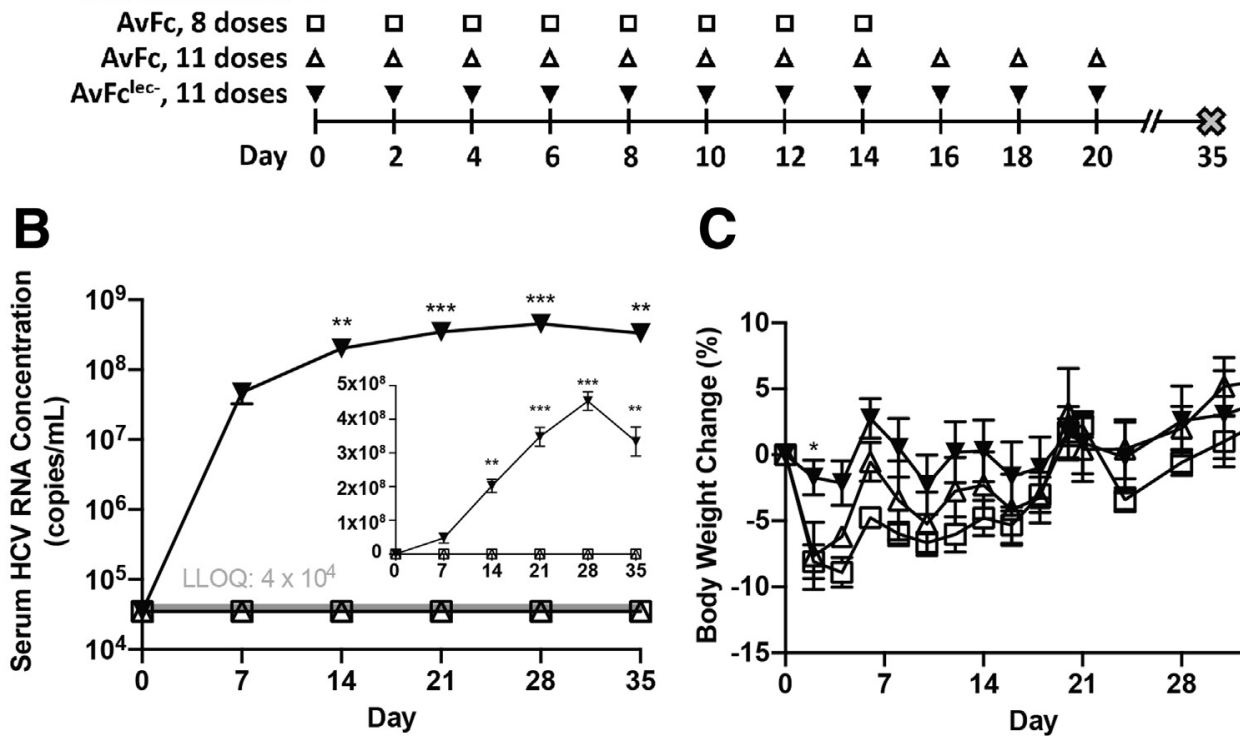

C

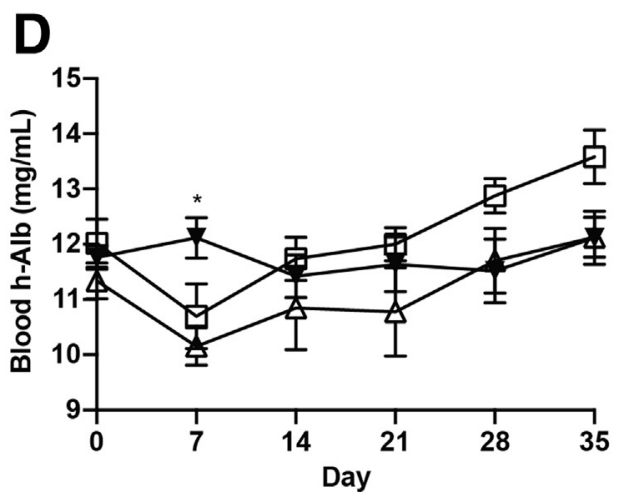

\section{$E$}

1140

Figure 8. The protective effect of AvFc against HCV challenge in PXB mice. $(A)$ Study design. PXB mice were challenged intraperitoneally with a HCV genotype 1 a virus on day 0 , simultaneously with an initial treatment intraperitoneally with either 25 $\mathrm{mg} / \mathrm{kg}$ of AvFc or AvFclec- Treatment was continued every other day for a total of 8 or 11 doses for AvFc and 11 doses for $\operatorname{AvFc}^{\text {lec- }}(\mathrm{n}=5$ each). The general conditions and body weights of the animals were monitored every other day, while serum HCV RNA and blood h-Alb levels were measured every 7 days. (B) Serum HCV RNA levels. AvFc treatment (both 8 and 11 doses) showed no detectable HCV RNA at any time point. The gray line indicates the lower limit of quantification, which was $4 \times 10^{4}$ copies $/ \mathrm{mL}$ in this assay. ${ }^{\star *} P<.01,{ }^{* \star *} P<.001$ (AvFclec- vs both AvFc 8 and 11 doses); 2 -way analysis of variance with ${ }^{\circ}$ the Tukey multiple comparison test. Inset: The graph shows the same data with the $y$-axis on a linear scale. (C-E) Time course of body weight change from day $0(C)$, blood h-Alb levels $(D)$, and serum h-Alt concentrations $(E)$. Each data point represents

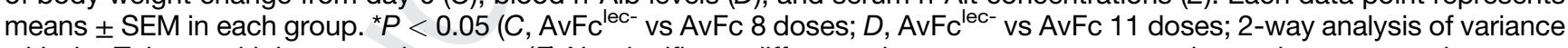
with the Tukey multiple comparison test. $(E)$ No significant difference between groups at any time point was noted.

at $4^{\circ} \mathrm{C}$ or room temperature. Absorbance at $280 \mathrm{~nm}$ and 600 $\mathrm{nm}$ was measured immediately after concentration and then again after 16 and 72 hours. $A_{280}$ was measured after centrifugation of precipitate.

\section{Pharmacokinetic Analysis}

A pharmacokinetic profile for AvFc was generated after a single $25-\mathrm{mg} / \mathrm{kg}$ intraperitoneal injection in C57bl/6 mice (The Jackson Laboratory, Bar Harbor, ME) (8-week-old males and females; $\mathrm{n}=4$ per time point) and sampling blood at $0.5,1,2,4,8,12,24$, and 48 hours after injection.
The concentration of AvFc then was measured using an HIV gp120-coated enzyme-linked immunosorbent assay. Briefly, a recombinant gp120 (HIV CM235; AIDS Reagent Program; National Institutes of Health, Bethesda, MD) was coated overnight at $0.3 \mu \mathrm{g} / \mathrm{mL}$ followed by blocking with $5 \%$ dry milk-PBST. Serum samples at varying dilutions were incubated for 2 hours, followed by detection by a goat antihuman Fc-horseradish-peroxidase secondary antibody (ThermoFisher Scientific). The plasma concentration of AvFc was calculated by interpolating from a standard curve. PK parameters were calculated using the PKSolver Microsoft Excel add-on. ${ }^{56}$
1156

1157

1158

1159

1160

1161

1162

1163

1164

1165

1166

1167

1168

1169

1170

1171

71172

1173

1174

1175

1176

1177 Q281178 
Toxicologic Analysis and HCV Challenge Study in

\section{PXB Mice}

The mouse model of toxicologic analysis and HCV infection and toxicologic analysis was performed in PXB mice (complementary DNA-uPA ${ }^{\text {wild/+ } / S C I D, ~ c o m p l e m e n-~}$

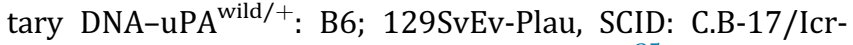
scid/scid Jcl; reviewed by Tateno and Kojima ${ }^{25}$ ). These mice contain transplanted human hepatocytes with a replacement index of greater than $70 \%$ as determined by blood hAlb measurements before virus inoculation. ${ }^{57}$ Blood h-Alb levels indicate the level and integrity of human hepatocyte engraftment in the mouse liver. Mice were separated into the following 3 treatment groups: $\mathrm{AvFc}^{\text {lec- }}(25 \mathrm{mg} / \mathrm{kg}, \mathrm{n}=5)$ for 11 doses, or AvFc (25 mg/kg, $\mathrm{n}=5$ each) for 8 or 11 doses. The initial treatment was co-administered intraperitoneally with virus inoculation $\left(5 \times 10^{5}\right.$ copies $\left./ \mathrm{kg}\right)$ on day 0 with a genotype $1 \mathrm{a}$ strain (PBC002), and treatment continued every other day thereafter. The general conditions and body weights of the animals were monitored every other day, while serum HCV RNA and blood h-Alb were measured every 7 days by RT-PCR or latex agglutination immunonephelometry (LZ Test Eiken U-ALB; Eiken Chemical Co, Ltd), respectively. The HCV RNA RT-PCR assay was developed based on the method described by Takeuchi et $\mathrm{al}^{58}$ with modifications, and validated by PhoenixBio for use in this animal model. The lower limit of quantification was determined to be $4.0 \times 10^{4}$ copies $/ \mathrm{mL}$. Serum ALT 1 levels were determined either using a Fujifilm DRI-CHEM NX500sV clinical chemistry instrument or by enzymelinked immunosorbent assay (Institute of Immunology Co, Ltd, Tokyo, Japan). At study termination on day 35, animals were killed and subject to gross necropsy and general health. Blood also was drawn via cardiac puncture and used for ALT, HCV RNA, and h-Alb analyses.

\section{Histopathologic Analysis of Liver Tissues}

H\&E-stained liver sections from 3 to 4 mice per group were generated by Nara Pathology Research Institute Co, Ltd (Nara, Japan) and evaluated by pathologists at SkyPatho, LLC. All slides were examined by a blinded, board-certified veterinary pathologist under a light microscope (BX43; Olympus Corporation, Tokyo, Japan). The tissues were assigned a severity score for a number of characteristics based on the 5-point scoring system of the CDISC SEND Controlled Terminology, as follows: 0, unremarkable; 1 , minimal; 2, mild; 3, moderate; 4, marked; 5, severe; and P, present.

\section{Statistical Analyses and Data Analysis}

Statistical significance was analyzed by GraphPad Prism 6 software (La Jolla, CA). Mouse body weights, albumin, ALT, and HCV RNA levels were compared using a repeatedmeasures 2-way analysis of variance with the Geisser-Greenhouse correction. Multiple comparisons between groups at each time point were conducted and corrected using the Tukey method with the threshold of significance set at $P=.05$. Liver:body-weight ratios were compared using 1-way analysis of variance. All authors had access to the study data, and reviewed and approved the final manuscript.

\section{References}

1. Penin F, Dubuisson J, Rey FA, Moradpour D, Pawlotsky JM. Structural biology of hepatitis C virus. Hepatology 2004;39:5-19.

2. Blach S, Zeuzem S, Manns M, Altraif I, Duberg A-S, Muljono DH, Waked I, Alavian SM, Lee M-H, Negro F. Global prevalence and genotype distribution of hepatitis C virus infection in 2015: a modelling study. Lancet Gastroenterol Hepatol 2017;2:161-176.

3. Zibbell JE, Asher AK, Patel RC, Kupronis B, Iqbal K, Ward JW, Holtzman D. Increases in acute hepatitis C virus infection related to a growing opioid epidemic and associated injection drug use, United States, 2004 to 2014. Am J Public Health 2018;108:175-181.

4. Zibbell JE, lqbal K, Patel RC, Suryaprasad A, Sanders KJ, Moore-Moravian L, Serrecchia J, Blankenship S, Ward JW, Holtzman D. Increases in hepatitis $C$ virus infection related to injection drug use among persons aged $\leq 30$ years-Kentucky, Tennessee, Virginia, and West Virginia, 2006-2012. MMWR Morb Mortal Wkly Rep 2015;64:453.

5. Manns MP, Buti M, Gane E, Pawlotsky J-M, Razavi H, Terrault N, Younossi Z. Hepatitis C virus infection. Nat Rev Dis Primers 2017;3:17006.

6. Negro F, Forton D, Craxì A, Sulkowski MS, Feld JJ, Manns MP. Extrahepatic morbidity and mortality of chronic hepatitis C. Gastroenterology 2015; 149:1345-1360.

7. Manns MP, McHutchison JG, Gordon SC, Rustgi VK, Shiffman M, Reindollar R, Goodman ZD, Koury K, Ling $\mathrm{M}-\mathrm{H}$, Albrecht JK. Peginterferon alfa-2b plus ribavirin compared with interferon alfa-2b plus ribavirin for initial treatment of chronic hepatitis $\mathrm{C}$ : a randomised trial. Lancet 2001;358:958-965.

8. Jacobson IM, McHutchison JG, Dusheiko G, Di Bisceglie AM, Reddy KR, Bzowej NH, Marcellin P, Muir AJ, Ferenci P, Flisiak R. Telaprevir for previously untreated chronic hepatitis $\mathrm{C}$ virus infection. $\mathrm{N}$ Engl J Med 2011;364:2405-2416.

9. Poordad F, McCone J Jr, Bacon BR, Bruno S, Manns MP, Sulkowski MS, Jacobson IM, Reddy KR, Goodman ZD, Boparai N. Boceprevir for untreated chronic HCV genotype 1 infection. N Engl J Med 2011; 364:1195-1206.

10. Asselah $\mathrm{T}$, Kowdley $\mathrm{KV}$, Zadeikis $\mathrm{N}$, Wang $\mathrm{S}$, Hassanein T, Horsmans $Y$, Colombo M, Calinas $F$, Aguilar $\mathrm{H}$, de Ledinghen $\mathrm{V}$, Mantry PS, Hezode $\mathrm{C}$, Marinho RT, Agarwal K, Nevens F, Elkhashab M, Kort J, Liu R, Ng TI, Krishnan P, Lin C-W, Mensa FJ. Efficacy of glecaprevir/pibrentasvir for 8 or 12 weeks in patients with hepatitis $C$ virus genotype 2, 4, 5, or 6 infection without cirrhosis. Clin Gastroenterol Hepatol 2018;16:417-426.

11. Afdhal N, Zeuzem S, Kwo P, Chojkier M, Gitlin N, Puoti M, Romero-Gomez M, Zarski J-P, Agarwal K, Buggisch P. Ledipasvir and sofosbuvir for untreated HCV genotype 1 infection. $N$ Engl $J$ Med 2014; 370:1889-1898. 
12. Feld JJ, Moreno C, Trinh R, Tam E, Bourgeois S, Horsmans Y, Elkhashab M, Bernstein DE, Younes Z, Reindollar RW. Sustained virologic response of $100 \%$ in HCV genotype $1 \mathrm{~b}$ patients with cirrhosis receiving ombitasvir/paritaprevir/r and dasabuvir for 12 weeks. J Hepatol 2016;64:301-307.

13. Zeuzem S, Ghalib R, Reddy KR, Pockros PJ, Ari ZB, Zhao Y, Brown DD, Wan S, DiNubile MJ, Nguyen B-Y. Grazoprevir-elbasvir combination therapy for treatmentnaive cirrhotic and noncirrhotic patients with chronic hepatitis $\mathrm{C}$ virus genotype 1, 4, or 6 infection: a randomized trial. Ann Intern Med 2015;163:1-13.

14. Fernández-Carrillo $\mathrm{C}$, Lens $\mathrm{S}$, Llop $\mathrm{E}$, Pascasio JM, Fernández I, Baliellas C, Crespo J, Buti M, Castells L, Romero-Gómez M, Pons C, Moreno JM, Albillos A, Fernández-Rodríguez $\mathrm{C}$, Prieto $\mathrm{M}$, FernándezBermejo M, García-Samaniego J, Carrión JA, de la Mata M, Badia E, Salmerón J, Herreros JI, Salcedo M, Moreno JJ, Turnes J, Granados R, Blé M, Calleja JL. Treatment of hepatitis $C$ virus in patients with advanced cirrhosis: always justified? Analysis of the Hepa-C Registry. J Hepatol 2016;64:S133.

15. Belli LS, Berenguer M, Cortesi PA, Strazzabosco M, Rockenschaub S-R, Martini S, Morelli C, Donato F, Volpes R, Pageaux G-P. Delisting of liver transplant candidates with chronic hepatitis $\mathrm{C}$ after viral eradication: a European study. J Hepatol 2016;65:524-531.

16. Jothimani D, Govil S, Rela M. Management of post liver transplantation recurrent hepatitis $\mathrm{C}$ infection with directly acting antiviral drugs: a review. Hepatol Int 2016; 10:749-761.

17. Hughes MG Jr, Tucker WW, Reddy S, Brier ME, Koch D, McClain CJ, Jonsson CB, Matoba N, Chung D. Rate of hepatitis $C$ viral clearance by human livers in human patients: liver transplantation modeling primary infection and implications for studying entry inhibition. PLoS One 2017;12:e0180719.

18. Felmlee DJ, Coilly A, Chung RT, Samuel D, Baumert TF. New perspectives for preventing hepatitis $C$ virus liver graft infection. Lancet Infect Dis 2016;16:735-745.

19. Colpitts CC, Baumert TF. Hepatitis C virus cell entry: a target for novel antiviral strategies to address limitations of direct acting antivirals. Hepatol Int 2016;10:741-748.

20. lacob RE, Perdivara I, Przybylski M, Tomer KB. Mass spectrometric characterization of glycosylation of hepatitis C virus E2 envelope glycoprotein reveals extended microheterogeneity of N-glycans. J Am Soc Mass Spectrom 2008;19:428-444.

21. Walls AC, Tortorici MA, Frenz B, Snijder J, Li W, Rey FA, DiMaio F, Bosch B-J, Veesler D. Glycan shield and epitope masking of a coronavirus spike protein observed by cryo-electron microscopy. Nat Struct Mol Biol 2016; 23:899-905.

22. Leonard CK, Spellman MW, Riddle L, Harris RJ, Thomas JN, Gregory TJ. Assignment of intrachain disulfide bonds and characterization of potential glycosylation sites of the type 1 recombinant human immunodeficiency virus envelope glycoprotein (gp120) expressed in Chinese hamster ovary cells. J Biol Chem 1990;265:10373-10382.
23. Suga A, Nagae M, Yamaguchi $Y$. Analysis of protein landscapes around $\mathrm{N}$-glycosylation sites from the PDB repository for understanding the structural basis of $\mathrm{N}$ glycoprotein processing and maturation. Glycobiology 2018;28:774-785.

24. Hamorsky KT, Kouokam JC, Dent MW, Grooms TN, Husk AS, Hume SD, Rogers KA, Villinger F, Morris MK, Hanson CV, Matoba N. Engineering of a lectibody targeting high-mannose-type glycans of the HIV envelope. Mol Ther 2019;27:2038-2052.

25. Tateno C, Kojima Y. Characterization and applications of chimeric mice with humanized livers for preclinical drug development. Lab Anim Res 2020;36:2.

26. Hamorsky KT, Grooms-Williams TW, Husk AS, Bennett LJ, Palmer KE, Matoba N. Efficient single tobamoviral vector-based bioproduction of broadly neutralizing anti-HIV-1 monoclonal antibody VRC01 in Nicotiana benthamiana plants and utility of VRC01 in combination microbicides. Antimicrob Agents Chemother 2013;57:2076-2086.

27. Goffard A, Callens N, Bartosch B, Wychowski C, Cosset F-L, Montpellier C, Dubuisson J. Role of N-linked glycans in the functions of hepatitis $\mathrm{C}$ virus envelope glycoproteins. J Virol 2005;79:8400-8409.

28. Meuleman $P$, Albecka A, Belouzard $S$, Vercauteren $K$, Verhoye L, Wychowski C, Leroux-Roels G, Palmer KE, Dubuisson J. Griffithsin has antiviral activity against hepatitis C virus. Antimicrob Agents Chemother 2011; 55:5159-5167.

29. Helle F, Wychowski C, Vu-Dac N, Gustafson KR, Voisset C, Dubuisson J. Cyanovirin-N inhibits hepatitis C virus entry by binding to envelope protein glycans. J Biol Chem 2006;281:25177-25183.

30. Hoque MM, Suzuki K, Tsunoda M, Jiang J, Zhang F, Takahashi A, Ohbayashi N, Zhang X, Tanaka H, Omura S, Takénaka A. Structural insights into the specific anti-HIV property of actinohivin: structure of its complex with the $\alpha(1-2)$ mannobiose moiety of gp120. Acta Crystallogr D Biol Crystallogr 2012;68:1671-1679.

31. Freedman H, Logan MR, Hockman D, Koehler Leman J, Law JLM, Houghton M. Computational prediction of the heterodimeric and higher-order structure of gpE1/gpE2 envelope glycoproteins encoded by hepatitis $\mathrm{C}$ virus. J Virol 2017;91:e02309-e02316.

32. Cholankeril G, Ahmed A. Alcoholic liver disease replaces hepatitis $C$ virus infection as the leading indication for liver transplantation in the United States. Clin Gastroenterol Hepatol 2018;16:1356-1358.

33. Wali M, Harrison R, Gow P, Mutimer D. Advancing donor liver age and rapid fibrosis progression following transplantation for hepatitis C. Gut 2002;51:248-252.

34. Colpitts CC, Chung RT, Baumert TF. Entry inhibitors: a perspective for prevention of hepatitis $C$ virus infection in organ transplantation. ACS Infect Dis 2017;3:620-623.

35. Baumert TF, Jühling F, Ono A, Hoshida Y. Hepatitis Crelated hepatocellular carcinoma in the era of new generation antivirals. BMC Med 2017;15:52.

36. Colpitts C, Baumert T. Addressing the challenges of hepatitis $C$ virus resistance and treatment failure. Multidisciplinary Digital Publishing Institute, 2016. 
37. Colpitts CC, Tsai PL, Zeisel MB. Hepatitis C virus entry: an intriguingly complex and highly regulated process. Int J Mol Sci 2020;21:2091.

38. Terrault N, Shrestha R, Satapathy SK, O'Leary JG, Campsen J, Rosenau J, Spivey J, Teperman LW, Therapondos G, Verna EC, Vierling JM, Schiano TD, Sher L, Khallafi $H$, Victor D, Bhamidimarri KR, Gordon FD, Hanish S, Kulik LM, Lake-Bakaar G, Maluf D, Porayko M, Bramer SL, Osgood G, Chavan S, Daelken N. LP17: Novel approach for the prevention of recurrent hepatitis $\mathrm{C}$ in liver transplant recipients: preliminary results from ongoing phase III trial with civacir. J Hepatol 2015;62:S271-S272.

39. Smith HL, Chung RT, Mantry P, Chapman W, Curry MP, Schiano TD, Boucher E, Cheslock P, Wang Y, Molrine DC. Prevention of allograft HCV recurrence with peri-transplant human monoclonal antibody MBLHCV1 combined with a single oral direct-acting antiviral: a proof-of-concept study. J Viral Hepat 2017; 24:197-206.

40. Helle F, Goffard A, Morel V, Duverlie G, McKeating J, Keck Z-Y, Foung S, Penin F, Dubuisson J, Voisset C. The neutralizing activity of anti-hepatitis $C$ virus antibodies is modulated by specific glycans on the E2 envelope protein. J Virol 2007;81:8101-8111.

41. Pantua $H$, Diao J, Ultsch $M$, Hazen $M$, Mathieu $M$, McCutcheon K, Takeda K, Date S, Cheung TK, Phung Q. Glycan shifting on hepatitis $\mathrm{C}$ virus (HCV) E2 glycoprotein is a mechanism for escape from broadly neutralizing antibodies. J Mol Biol 2013; 425:1899-1914.

42. Balzarini J. Targeting the glycans of glycoproteins: a novel paradigm for antiviral therapy. Nat Rev Microbiol 2007;5:583-597.

43. Peters L, Klein MB. Epidemiology of hepatitis $C$ virus in HIV-infected patients. Curr Opin HIV AIDS 2015; 10:297-302.

44. Schranz AJ, Barrett J, Hurt CB, Malvestutto C, Miller WC. Challenges facing a rural opioid epidemic: treatment and prevention of HIV and hepatitis C. Curr HIV/AIDS Rep 2018;15:245-254.

45. Ruck JM, Segev DL. Expanding deceased donor kidney transplantation: medical risk, infectious risk, hepatitis C virus, and HIV. Curr Opin Nephrol Hypertens 2018; 27:445-453.

46. Bodzin AS, Baker TB. Liver transplantation today: where we are now and where we are going. Liver Transpl 2018; 24:1470-1475.

47. Nakabayashi H, Taketa K, Miyano K, Yamane T, Sato J. Growth of human hepatoma cell lines with differentiated functions in chemically defined medium. Cancer Res 1982;42:3858-3863.

48. Wakita $T$, Pietschmann $T$, Kato $T$, Date $T$, Miyamoto $M$, Zhao Z, Murthy K, Habermann A, Kräusslich H-G, Mizokami M. Production of infectious hepatitis $C$ virus in tissue culture from a cloned viral genome. Nat Med 2005; 11:791.

49. Goueslain L, Alsaleh $K$, Horellou $P$, Roingeard $P$, Descamps V, Duverlie G, Ciczora Y, Wychowski C, Dubuisson J, Rouillé $Y$. Identification of GBF1 as a cellular factor required for hepatitis C virus RNA replication. J Virol 2010;84:773-787.

50. Maurin G, Fresquet J, Granio O, Wychowski C, Cosset F$\mathrm{L}$, Lavillette D. Identification of interactions in the E1E2 heterodimer of hepatitis $C$ virus important for cell entry. J Biol Chem 2011;286:23865-23876.

51. Scheel TK, Gottwein JM, Jensen TB, Prentoe JC, Hoegh AM, Alter HJ, Eugen-Olsen J, Bukh J. Development of JFH1-based cell culture systems for hepatitis $\mathrm{C}$ virus genotype $4 \mathrm{a}$ and evidence for cross-genotype neutralization. Proc Natl Acad Sci U S A 2008; 105:997-1002.

52. Jensen TB, Gottwein JM, Scheel TK, Hoegh AM, EugenOlsen J, Bukh J. Highly efficient JFH1-based cell-culture system for hepatitis $\mathrm{C}$ virus genotype $5 \mathrm{a}$ : failure of homologous neutralizing-antibody treatment to control infection. J Infect Dis 2008;198:1756-1765.

53. Gottwein JM, Scheel TK, Jensen TB, Lademann JB, Prentoe JC, Knudsen ML, Hoegh AM, Bukh J. Development and characterization of hepatitis $C$ virus genotype 1-7 cell culture systems: role of CD81 and scavenger receptor class B type I and effect of antiviral drugs. Hepatology 2009;49:364-377.

54. De Beeck AO, Voisset C, Bartosch B, Ciczora Y, Cocquerel L, Keck Z, Foung S, Cosset F-L, Dubuisson J. Characterization of functional hepatitis $C$ virus envelope glycoproteins. J Virol 2004;78:2994-3002.

55. Dubuisson J, Hsu HH, Cheung RC, Greenberg HB, Russell DG, Rice CM. Formation and intracellular localization of hepatitis $C$ virus envelope glycoprotein complexes expressed by recombinant vaccinia and Sindbis viruses. J Virol 1994;68:6147-6160.

56. Zhang $\mathrm{Y}$, Huo M, Zhou J, Xie S. PKSolver: An add-in program for pharmacokinetic and pharmacodynamic data analysis in Microsoft Excel. Comput Methods Programs Biomed 2010;99:306-314.

57. Ji C, Liu Y, Pamulapati C, Bohini S, Fertig G, Schraeml M, Rubas W, Brandt M, Ries S, Ma $H$, Klumpp K. Prevention of hepatitis $C$ virus infection and spread in human liver chimeric mice by an anti-CD81 monoclonal antibody. Hepatology 2015;61:1136-1144.

58. Takeuchi T, Katsume A, Tanaka T, Abe A, Inoue K, Tsukiyama-Kohara K, Kawaguchi R, Tanaka S, Kohara M. Real-time detection system for quantification of hepatitis C virus genome. Gastroenterology 1999; 116:636-642.

Received May 20, 2020. Accepted August 25, 2020.

\section{Correspondence}

Address correspondence to: Nobuyuki Matoba, Department of Pharmacology and Toxicology, University of Louisville School of Medicine, 505 S Hancock Street, Room 615, Louisville, Kentucky 40202. e-mail: n.matoba@louisville.edu; fax: (xxx) xxx-xxxx.

Acknowledgments

CRediT Authorship Contributions: Matthew Dent (Data curation: Equal; Formal analysis: Lead; Investigation: Equal; Validation: Supporting; Writing - origina draft: Lead); Krystal Hamorsky (Formal analysis: Supporting; Writing - review \& editing: Supporting); Thibaut Vausseline (Data curation: Equal; Formal analysis: Equal; Investigation: Supporting; Writing - review \& editing: Supporting); Jean Dubuisson (Formal analysis: Supporting; Funding acquisition: Supporting; Investigation: Supporting; Methodology: Supporting; Supervision: Supporting; Validation: Equal; Writing - review \& editing:
1474

1475

1476

1477

1478

1479

1480

1481

1482

1483

1484

1485

1486

1487

1488

1489

1490

1491

1492

1493

1494

1495

1496

1497

1498

1499

1500

1501

1502

1503

1504

1505

1506

1507

1508

1509

1510

1511

1512

1513

1514

1515

1516

1517

1518

1519

1520

1521

1522

1523

1524

Q3P425

1526

1527

1528

1529

1530

1531

1532 
Supporting); Yoshinari Miyata (Data curation: Supporting; Formal analysis: Supporting; Investigation: Supporting; Methodology: Supporting; Project administration: Supporting; Validation: Equal; Writing - review \& editing: Supporting); Yoshio Morikawa (Investigation: Supporting; Project administration: Supporting; Supervision: Supporting; Validation: Supporting; Writing - review \& editing: Supporting); Nobuyuki Matoba, PhD (Conceptualization: Lead; Data curation: Equal; Formal analysis: Supporting; Funding acquisition: Lead; Investigation: Lead; Methodology: Lead; Project administration: Lead; Supervision: Lead; Validation: Equal; Writing - original draft: Supporting; Writing - review \& editing: Lead)

The authors thank Adeline Danneels, Lucie Fénéant, Czeslaw Wychowski, Lauren Moore, and Jessica Jurkiewicz for their experimental help. The authors also are grateful to R. Bartenschlager, J. Bukh, F.L. Cosset, M. Harris, and T. Wakita for providing essential reagents. The immunofluorescence analyses were performed with the help of the imaging core facility of the Biolmaging Center Lille Nord-de-France.

1592

Conflicts of interest

This author discloses the following: Nobuyuki Matoba is an inventor on a patent concerning the composition and utility of Avaren-Fc (US patent number 8802822). The remaining authors disclose no conflicts.

\section{Funding}

This work was supported by the University of Louisville ExCITE program, which was funded by US National Institutes of Health (U01 HL127518) and the Leona M. and Harry B. Helmsley Charitable Trust. Avaren- $\mathrm{Fc}^{\text {lec- }}$ was created from work supported by a National Institutes of Health grant (R33 Al088585).
1594 